SILVA, A. L.; CARLOS, H. C. V.; RIVABEN, R. C.; SILVA, L. J.; DIAS, D. C. F. S.; MORAIS, G. A.; LIMA, L. B. Tetrazolium and interaction of temperature and light under seed germination in Ormosia arborea (Fabaceae). Revista de Agricultura Neotropical, Cassilândia-MS, v. 8, n. 1, e5206, jan./mar. 2021. ISSN 2358-6303. DOI: https://doi.org/10.32404/rean.v8i1.5206.

\title{
Tetrazolium and interaction of temperature and light under seed germination in Ormosia arborea (Fabaceae)
}

\section{Aparecida Leonir da Silva ${ }^{1}$, Halisson César Vinci Carlos ${ }^{2}$, Rodrigo Cyrino Rivaben², Laércio Junio Silva ${ }^{3}$, Denise Cunha Fernandes dos Santos Dias ${ }^{3}$, Glaucia Almeida de Morais ${ }^{4}$, Liana Baptista de Lima ${ }^{2}$}

\author{
${ }^{1}$ Universidade Federal de Viçosa, Departamento de Biologia Vegetal, Viçosa, Minas Gerais, Brasil. E-mail: \\ aparecidaleonir@gmail.com \\ ${ }^{2}$ Universidade Federal de Mato Grosso do Sul, Instituto de Biociências, Campo Grande, Mato Grosso do Sul, Brasil. E-mail: \\ halissonvinci14@hotmail.com, rodrigorivaben@gmail.com, lianablima3@gmail.com \\ ${ }^{3}$ Universidade Federal de Viçosa, Departamento de Fitotecnia, Viçosa, Minas Gerais, Brasil. E-mail: laercio.silva@ufv.br, \\ dcdias@ufv.br \\ ${ }^{4}$ Universidade Estadual de Mato Grosso do Sul, Unidade Universitária de Ivinhema, Ivinhema, Mato Grosso do Sul, Brasil. E-mail: \\ gamorais@uems.br
}

Received: 02/07/2020; Accepted: 27/01/2021.

\section{ABSTRACT}

The study aimed to define the best conditions to conduct germination tests for Ormosia arborea seeds and assess the viability of seeds using the tetrazolium test. The germination tests were conducted at temperatures of 10,15 , $20,25,30$, and $35{ }^{\circ} \mathrm{C}$ and alternating temperatures of $20-30{ }^{\circ} \mathrm{C}$, in the presence or absence of light. For the tetrazolium test, seeds were immersed in tetrazolium solution $0.075 \%$, at $35^{\circ} \mathrm{C}$ for three hours, and then the viability was evaluated. It was verified that the seeds did not present absolute photosensitivity. The tetrazolium test was effective in separating the seeds into two categories concerning seed viability, viable and nonviable. It was concluded that $O$. arborea seeds germinate in the presence or absence of light in a wide range of temperatures. Temperatures of 25 and $30^{\circ} \mathrm{C}$ and alternating temperatures of $20-30{ }^{\circ} \mathrm{C}$ are indicated to conduct germination tests. The tetrazolium test was effective in assessing seed viability.

Keywords: Olho de cabra, Tetrazolium test, Native species.

\section{Tetrazólio e interação temperatura e luz na germinação de sementes de Ormosia arborea (Fabaceae)}

\section{RESUMO}

O estudo teve como objetivo definir as melhores condições para os testes de germinação de sementes de Ormosia arborea e avaliar a viabilidade das sementes utilizando o teste de tetrazólio. $\mathrm{O}$ teste de germinação foi realizado nas temperaturas de $10,15,20,25,30$ e $35^{\circ} \mathrm{C}$ e em temperaturas alternadas de $20-30{ }^{\circ} \mathrm{C}$, na presença ou ausência de luz. Para o teste de tetrazólio, as sementes foram imersas em solução de tetrazólio $0,075 \%$, a $35{ }^{\circ} \mathrm{C}$ por três horas, e a viabilidade foi avaliada. Verificou-se que as sementes não apresentaram fotossensibilidade absoluta. $\mathrm{O}$ teste do tetrazólio foi eficaz na classificação das sementes em duas categorias, quanto à viabilidade, viável e não viável. Concluiu-se que as sementes de $O$. arborea germinam na presença ou ausência de luz em uma ampla faixa de temperaturas. São indicadas as temperaturas de $25,30{ }^{\circ} \mathrm{C}$ e alternada de $20-30{ }^{\circ} \mathrm{C}$ para o teste de germinação. $\mathrm{O}$ teste de tetrazólio foi eficaz na avaliação da viabilidade das sementes.

Palavras-chave: Olho de cabra, Teste de tetrazólio, Espécies nativas. 


\section{Introduction}

Ormosia arborea (Vell.) Harms belongs to the Fabaceae family and is popularly known in Brazil as olho-de-cabra. Mainly found in the Atlantic rainforest and the broadleaf semideciduous forest, this species occurs in Bahia and Minas Gerais states and from Mato Grosso do Sul to Santa Catarina (Lorenzi, 2000). The trees are used for urban forestation in streets and avenues besides degraded lands (Lorenzi, 2000).

$O$. arborea is a native species propagated by seeds, and the success in seedling production depends on the knowledge regarding the germination process and seed quality. The germination process is influenced by external factors that include temperature, water, oxygen, and internal factors such as dormancy (Marcos-Filho, 2015). O. arborea seeds exhibit primary dormancy, which is characterized as the expression of dormancy as soon as its development is complete; that is, when harvested, the seeds present this type of dormancy (Lorenzi, 2000; Silva et al., 2014; Naves et al., 2018). According to Silva and Morais (2012), the most efficient method to overcome this dormancy is the chemical scarification in sulfuric acid for 20 minutes.

Temperature is a factor that influences the speed and uniformity of germination because it affects biochemical reactions that are involved in the process. The optimal germination temperature of a given species is when a higher percentage of germination occurs in the shortest time (Bewley and Black, 1982; Fenner, 2000; MarcosFilho, 2015). In general, temperatures too high or too low inhibit this process. Hence, each species presents an optimal germination temperature related to climatic conditions from where the species naturally occur (Valadares and Paula, 2008).

In many species, seed germination is stimulated by light, whereas in other species, the light may inhibit germination. Seeds that require light for germination are positively photoblastic. Those that germinate better when there is a light limitation are negatively photoblastic, and those that are indifferent are lightly insensible (Lopes et al., 2005; Merai et al., 2019).

The ideal conditions for conducting the germination test, regarding temperature, light, and substrate, must be identified, aiming to identify the best conditions for the seeds of each species. Combinations of light and temperature must be assessed, and by doing so, one can gain insight into the species biology and its needs in the field.

The germination test has been the most widely utilized method to evaluate seed viability. However, for native species, germination might require longer periods. For example, in $O$. arborea, the mean germination time, when evaluating different methods for overcoming seed dormancy, ranged from eight to 14 days (Silva et al., 2014). Therefore, it is important to develop and improve quick methods that evaluate seed viability and characterizes its physiological potential.

The tetrazolium test stands out from other tests as a method for evaluating seed viability and vigor based on the enzymatic activity of the dehydrogenase enzyme group in live tissues (Costa and Santos, 2010). This test is faster than the germination test and provides a diagnosis of seed quality (França-Neto and Krzyzanowski, 2019). In this sense, some researches had been carried out with forest species defining the methodology for conducting the tetrazolium test, such as in Leucaena leucocephala (Lam.) (Costa and Santos, 2010), Helianthus annuus (Silva et al., 2013), Plinia cauliflora (Hössel et al., 2013), Acca sellowiana (Sarmento et al., 2018), Eugenia brasiliensis, Eugenia pyriformis (Lamarca and Barbedo, 2014), Tabebuia roseoalba (Abbade and Takaki, 2014), Eugenia uniflora (Kaiser et al., 2014), Apuleia moralis (Reis et al., 2016) and Jatropha curcas (Araújo et al., 2019).

Considering the lack of information regarding optimal temperature, photoblatism, and the efficiency of the tetrazolium test for $O$. arborea seeds, this study aimed to evaluate the germination of seeds under different temperature and light conditions and assess seed viability by the tetrazolium test.

\section{Material and Methods}

Seeds of $O$. arborea were collected from parent plants located in the left margin of the Ivinhema river $\left(22^{\circ}\right.$ 03'04,5" S; $53^{\circ} 41$ '28,2" W), in Nova Andradina, Mato Grosso do Sul state, in August of 2011 and stored for two years in a refrigerator at $10^{\circ} \mathrm{C}$.

Initially, to overcome dormancy, seeds were chemically scarified with sulfuric acid for 20 minutes and subsequently washed in running water for 5 minutes (Silva and Morais, 2012). Non-scarified seeds were used as a control group in each temperature.

In sequence, seeds were distributed between three paper towels (two paper towels underneath and one over the seeds) and wetted with distilled water. The proportion of water was 2.5 times the dry weight of the paper. The paper towels sheets were then turned into rolls and were wrapped and kept in a germination chamber for up to 120 days. The sheets of paper towels were changed whenever necessary and were hydrated as needed to keep the substrate always moist.

The seeds were allowed to germinate under constant temperatures: $10,15,20,25,30$ and $35^{\circ} \mathrm{C}$ in the presence of light (12 hours daily) and absence of light and, under alternating temperatures of $20-30{ }^{\circ} \mathrm{C}(12$ hours daily at 30 ${ }^{\circ} \mathrm{C}$ in the presence of light, and at $20^{\circ} \mathrm{C}$ in the absence of light).

In the absence of light, the germination tests were conducted in a dark room, using a green light during the 
evaluation of these treatments. For each temperature (10, $15,20,25,30,35^{\circ} \mathrm{C}$ and $20-30^{\circ} \mathrm{C}$ ) and light conditions (presence and absence of light), four replicates with 50 seeds each were utilized.

The number of seeds showing primary root emissions (seeds that showed a primary root of at least $2 \mathrm{~mm}$ of length) and the number of germinated seeds (normal seedlings, showing all the essential structures well developed) were registered daily. The mean germination time, the mean germination speed, and the relative frequency of germination were calculated using the daily data. The mean germination time and the mean germination speed were calculated according to the following formulas (Labouriau and Valadares, 1976):

$$
t=\frac{\left[\sum_{i=1}^{k} n i . t i\right]}{\sum_{i=1}^{k} n i}
$$

Where $\mathrm{t}=$ mean germination time; $n_{\mathrm{i}}=$ number of germinated seeds per day; $\mathrm{ti}=$ time (days).

$$
V=\frac{1}{t}
$$

Where $\mathrm{V}=$ mean germination speed; $\mathrm{t}=$ mean germination time.

The relative frequency was calculated according to Labouriau and Pacheco (1978):

$$
F r=\frac{n i}{\sum_{i=1}^{k} n i}
$$

Where Fr = relative frequency of germination; $n_{\mathrm{i}}=$ number of germinated seeds per day; $\Sigma n_{\mathrm{i}}=$ total number of germinated seeds.

The criteria used to classify seedlings as having normal features are described in Brasil (2009). For the studied species, seedlings showing the absence of one of the eophylls were considered abnormal.

The tetrazolium test was conducted to analyze its applicability in evaluating the seed viability of $O$. arborea. Currently, there is no information about the tetrazolium test for this species in the literature. A total of 300 seeds was mechanically scarified with 100-grit sandpaper and subsequently immersed in distilled water for 120 hours in B.O.D., at $25^{\circ} \mathrm{C}$, to assure that all seeds were fully imbibed.

Seeds of three replicates of 100 seeds had their coat removed and were longitudinally cut. Each replicate was immersed in a tetrazolium solution (2,3,5-triphenyltetrazolium chloride), at a concentration of $0,075 \%$, and kept in an incubator at $35{ }^{\circ} \mathrm{C}$, for three hours. After that period, seeds were washed with running water and left submerged in water until the evaluation moment.

The seeds were classified as viable or unviable according to characteristics observed and, in the patterns indicated by Moore (1972), considering the integrity of the tissues, location, extension, and intensity of the color and the presence of milky-white areas concerning the essential areas for the development of the embryo (hypocotyl-radicle axis and cotyledons). In this way, the bright red or bright pink colors were related to the living and vigorous tissues, the crimson red to the deteriorating tissues, and white or yellowish to the dead tissues. Seeds were considered viable when the embryo presented bright pink and bright red coloring, milkywhite seeds were considered unviable, as well as seeds showing embryo parts with milky white color. The results of the tetrazolium test were compared to the germination test.

Statistical design. The experiment was carried out with a completely randomized design in a $2 \times 7$ factorial scheme. Two light conditions (presence and absence of light) and seven temperatures (10, 15, 20, 25, 30, 35, and alternate $20-30{ }^{\circ} \mathrm{C}$ ) were evaluated. The percentage data (seeds showing primary root emission and germinated seeds) were transformed using the function $\operatorname{arcsen} \sqrt{x / 100}$. When significant in ANOVA, the means obtained for the temperatures were compared by Tukey test at $5 \%$ probability. The F test compared the means obtained for the treatments with the presence and absence of light at a $5 \%$ probability.

\section{Results and Discussion}

In intact seeds of $O$. arborea (control), the maximum percentage of seeds showing primary root emission was only $2 \%$, and for this reason, their data was not included in the analysis. These results agree with Silva et al. (2014), the species has tegumentary dormancy, and to germinate these seeds, this dormancy needs to be broken.

The chemical scarification method resulted in a higher percentage of seeds showing primary root emission (above 70\%), proving the efficacy of the method to overcome seed dormancy (Table 1). Furthermore, these seeds were stored for two years before the germination test. This result shows the importance of dormancy for the survival of this species, which maintained high viability even after the storage period. Moreover, these seeds are orthodox, supporting storage at low temperatures $\left(10^{\circ} \mathrm{C}\right.$, in the fridge) for two years.

It was verified that the seeds of $O$. arborea did not present absolute photosensitivity. A higher percentage of seeds showing primary root emission was observed in the absence of light from 15 to $30^{\circ} \mathrm{C}$. However, at the alternate $20-30{ }^{\circ} \mathrm{C}$, the seeds showing the percentage of primary root emission was indifferent to the presence of light only in the extreme temperatures (sub and supra optimum) of 10 and $35^{\circ} \mathrm{C}$ (Table 1). 
Table 1. Percentage of seeds showing primary root emission, percentage of germination, mean germination time, and mean germination speed of Ormosia arborea seeds, chemically scarified in sulfuric acid for 20 minutes, kept at different temperatures $(10,15,20,25,30$, 35 e $\left.20-30{ }^{\circ} \mathrm{C}\right)$, in the presence and absence of light.

\begin{tabular}{|c|c|c|c|c|c|c|c|c|}
\hline \multirow{2}{*}{ Temp $\left({ }^{\circ} \mathrm{C}\right)$} & \multicolumn{2}{|c|}{ Primary root emission $(\%)$} & \multicolumn{2}{|c|}{ Germination $(\%)$} & \multicolumn{2}{|c|}{ Mean germination time (days) } & \multicolumn{2}{|c|}{ Mean germination speed } \\
\hline & Light & Dark & Light & Dark & Light & Dark & Light & Dark \\
\hline 10 & $79 \mathrm{Aa}$ & $81 \mathrm{Ab}$ & $0 \mathrm{Ac}$ & $0 \mathrm{Ad}$ & $0 \mathrm{Aa}$ & $0 \mathrm{Aa}$ & $0 \mathrm{Ae}$ & $0 \mathrm{Ae}$ \\
\hline 15 & $80 \mathrm{Ba}$ & $94 \mathrm{Aab}$ & $67 \mathrm{Aa}$ & $74 \mathrm{Abc}$ & $83,2 \mathrm{Bf}$ & $74 \mathrm{Ad}$ & $0,82 \mathrm{Ad}$ & $0,99 \mathrm{Ad}$ \\
\hline 20 & $84 \mathrm{Ba}$ & 94 Aab & $78 \mathrm{Aa}$ & $84 \mathrm{Aabc}$ & $40,1 \mathrm{Ae}$ & $46,2 \mathrm{Bc}$ & $1,97 \mathrm{Abc}$ & 1,62 Acd \\
\hline 25 & $77 \mathrm{Ba}$ & $96 \mathrm{Aab}$ & $71 \mathrm{Ba}$ & $89 \mathrm{Aab}$ & $26,1 \mathrm{Ac}$ & $30,9 \mathrm{Bb}$ & 2,74 Aab & 2,94 Aa \\
\hline 30 & $70 \mathrm{Ba}$ & $90 \mathrm{Aab}$ & 62 & $78 \mathrm{Abc}$ & $19,3 \mathrm{Ab}$ & $28,6 \mathrm{Bb}$ & $3,31 \mathrm{Aa}$ & 2,82 Aab \\
\hline 35 & $79 \mathrm{Aa}$ & $85 \mathrm{Aab}$ & $41 \mathrm{Bb}$ & $67 \mathrm{Ac}$ & $34,8 \mathrm{Ad}$ & $32,3 \mathrm{Ab}$ & $1,24 \mathrm{Bcd}$ & $2,17 \mathrm{Abc}$ \\
\hline $20-30$ & $85 \mathrm{Ba}$ & $98 \mathrm{Aa}$ & $79 \mathrm{Ba}$ & $95 \mathrm{Aa}$ & $25,9 \mathrm{Ac}$ & $29,9 \mathrm{Bb}$ & $3,11 \mathrm{Aa}$ & $3,31 \mathrm{Aa}$ \\
\hline $\mathrm{CV}(\%)$ & \multicolumn{2}{|c|}{7,1} & \multicolumn{2}{|c|}{11,1} & \multicolumn{2}{|c|}{5,9} & \multicolumn{2}{|c|}{18,2} \\
\hline
\end{tabular}

Means followed by the same lowercase letters in the column do not differ by the Tukey test at 5\% probability. Means followed by the same uppercase letter comparing light and dark conditions do not differ by the $\mathrm{F}$ test at $5 \%$ probability.

Similar results were found by Teixeira et al. (2011) concerning the absolute requirement of light. In this case, seeds of $O$. arborea did not present an absolute requirement for light; conversely, they presented a tendency to a higher percentage of primary root emission in the absence of light. Other species are also indifferent to the light requirement for seed germination, as it was verified for Magonia pubescens St. Hil. (Souza Filho et al., 2012) and Kielmeyera coriacea Mart. \& Zucc. (Pimenta et al., 2011).

In light conditions, the temperature did not affect the primary root emission percentage of $O$. arborea seeds. In the absence of light, the highest primary root emission percentage was obtained by alternating temperatures of $20-30{ }^{\circ} \mathrm{C}(98 \%)$; however, this value was superior only to the germination percentage obtained at $10^{\circ} \mathrm{C}$ (Table 1).

During the period of evaluation (120 days), seed germination was not observed at the temperature of $10^{\circ} \mathrm{C}$ (Table 1), a result also found by Rosseto et al. (2009) in Parkia pendula seeds. For $P$. pendula, the temperatures of 10 and $15{ }^{\circ} \mathrm{C}$ inhibited the formation of the normal seedling.

The germination percentage was higher in the absence than the presence of light for the temperatures of $25,30,35^{\circ} \mathrm{C}$ and the at alternating temperature (20-30 ${ }^{\circ} \mathrm{C}$ ) (Table 1). In the presence of light, there was a higher percentage of seed germination at the alternating temperature of $20-30{ }^{\circ} \mathrm{C}(79 \%)$ (Table 1). However, this value only differed from those obtained at $10^{\circ} \mathrm{C}(0 \%)$ and $35^{\circ} \mathrm{C}(41 \%)$ (Table 1). In the absence of light, the higher germination percentage was also obtained in alternating temperatures of $20-30{ }^{\circ} \mathrm{C}$, not differing at 20 and $25^{\circ} \mathrm{C}$ (Table 1).

In a study by Brancalion et al. (2010), which evaluated the optimal germination temperature of tree native species in Brazil, it was found that the species in which alternating temperatures are exclusively indicated as optimal are typically early species in the forest succession. However, according to the same authors, many species that are last in the forest succession also have germination favored by alternating temperatures.
Thus, alternating temperatures may be essential to overcome the physical and physiological dormancy of pioneer species, even though later species in the successional stage may benefit from it.

Several studies have shown that with alternating temperature is possible to overcome the physical dormancy (Souza et al., 2012; Daibes et al., 2017; Jaganathan et al., 2019). Temperature is probably the factor involved in overcoming physical dormancy in Schizolobium parahyba var. parahyba, a forest gap species from the Brazilian Atlantic Forest (Souza et al., 2012). According to these authors, alternating temperatures $20-30{ }^{\circ} \mathrm{C}$ overcame dormancy faster than the constant high temperature at $30{ }^{\circ} \mathrm{C}$. Phytelephas macrocarpa presents morpho-physiological dormancy, and the stratification at alternating temperatures (26 to 40 ${ }^{\circ} \mathrm{C}$ ) helped to overcome seed dormancy (Ferreira and Gentil, 2017).

Due to the wide range of temperatures in which relatively high germination percentages were obtained, this species presents great ecological plasticity capable of germinating in many environmental conditions. This ecological plasticity increases the chances of success in recruiting seeds in their natural environment, where they may be subject to high irradiances and a great temperature variation. However, it is not recommended to initiate the production of seedlings when temperatures are low.

Larcher (2006) highlighted that for species with wide distribution, as well as for those adapted to large temperature fluctuations in their habitat, the temperature range for germination is extensive. According to the author, the optimal temperature for tropical species in natural conditions lies between $20^{\circ} \mathrm{C}$ and $35^{\circ} \mathrm{C}$. On the other hand, and to a certain limit, the increase in temperature may promote changes in the performance of certain enzymes, which play important roles in the biochemical processes of germination and may favor the contamination by microorganisms.

As for the effect of alternating temperature, its response is difficult to quantify. According to Cardoso 
(2004), it may vary according to exposure time, the variation range of high and low temperatures, and the number of exposure cycles, among other aspects.

It is noteworthy that the reasons regarding what determines the effect of alternating temperatures are not well known. Still, it is supposed that temperature variation may affect the promoter/inhibitor balance of the germination. Promoter/inhibitor concentration is lower at lower temperatures, while in higher temperatures, promotor concentration tends to increase (Huarte and Benech-Arnold, 2010; Footitt et al., 2011; Marcos-Filho, 2015).

The optimal temperature is the one that efficiently combines the percentage and speed of germination (Bewley and Black, 1982; Marcos-Filho, 2015; Fenner, 2000). The author Marcos-Filho (2015) highlights that the gradual reduction of temperature causes a sharp decrease in germination speed due to the effects on imbibition speed and reserve mobilization. This process contributes to a greater seed sensibility to adverse environmental factors.

When the mean germination speed data is compared between treatments (Table 1), a higher germination speed was observed in the presence and absence of light, at the temperatures of 25 and $30{ }^{\circ} \mathrm{C}$, and in the alternating temperatures of $20-30{ }^{\circ} \mathrm{C}$. (Table 1). O. arborea seeds can germinate both in the presence and absence of light and germinate from 15 to $35^{\circ} \mathrm{C}$ and under alternating temperature $\left(20-30{ }^{\circ} \mathrm{C}\right)$. When the data of mean germination speed was compared in presence or absence of light in the same temperature, it was possible to see that just at $35^{\circ} \mathrm{C}$ in the absence was better than in the presence of light (Table 1). In general, alternating temperatures in the absence of light provided a higher percentage of seeds showing primary root emission and seed germination.

The lowest Mean germination time for seed germination occurred at $30^{\circ} \mathrm{C}$ in the presence of light, while for the absence of light, the lowest mean germination time occurred at $25,30,35$, and 20-30 ${ }^{\circ} \mathrm{C}$. The temperatures of 25,30 , and $20-30^{\circ} \mathrm{C}$ promoted faster germination speeds both in the absence and presence of light (Figure 1). In another study with the same species, the authors indicated the temperature of $30^{\circ} \mathrm{C}$ as the best for seed germination on the substrate containing sand (Oliveira et al., 2016).
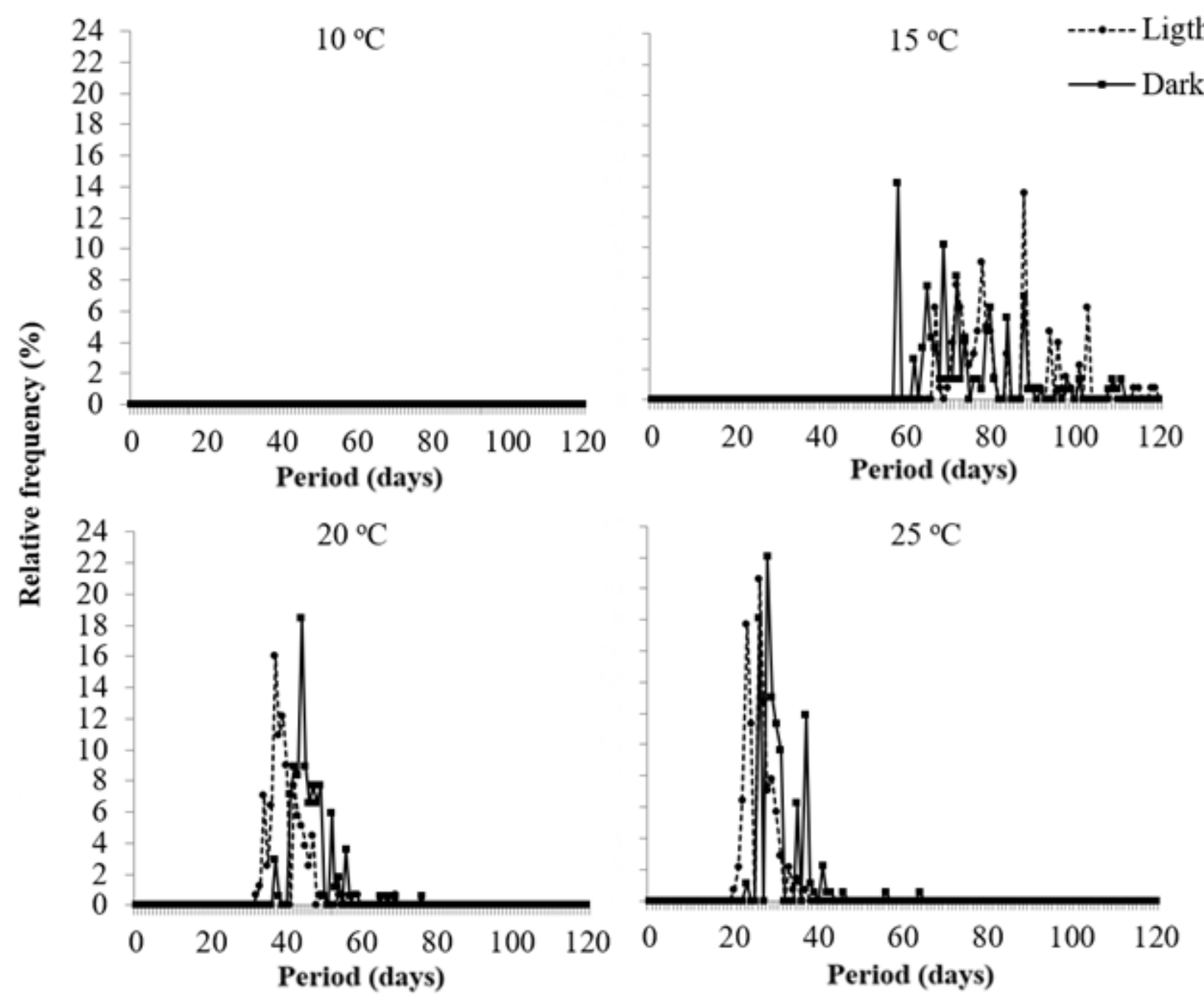

Revista de Agricultura Neotropical, Cassilândia-MS, v. 8, n. 1, e5206, jan./mar. 2021. 

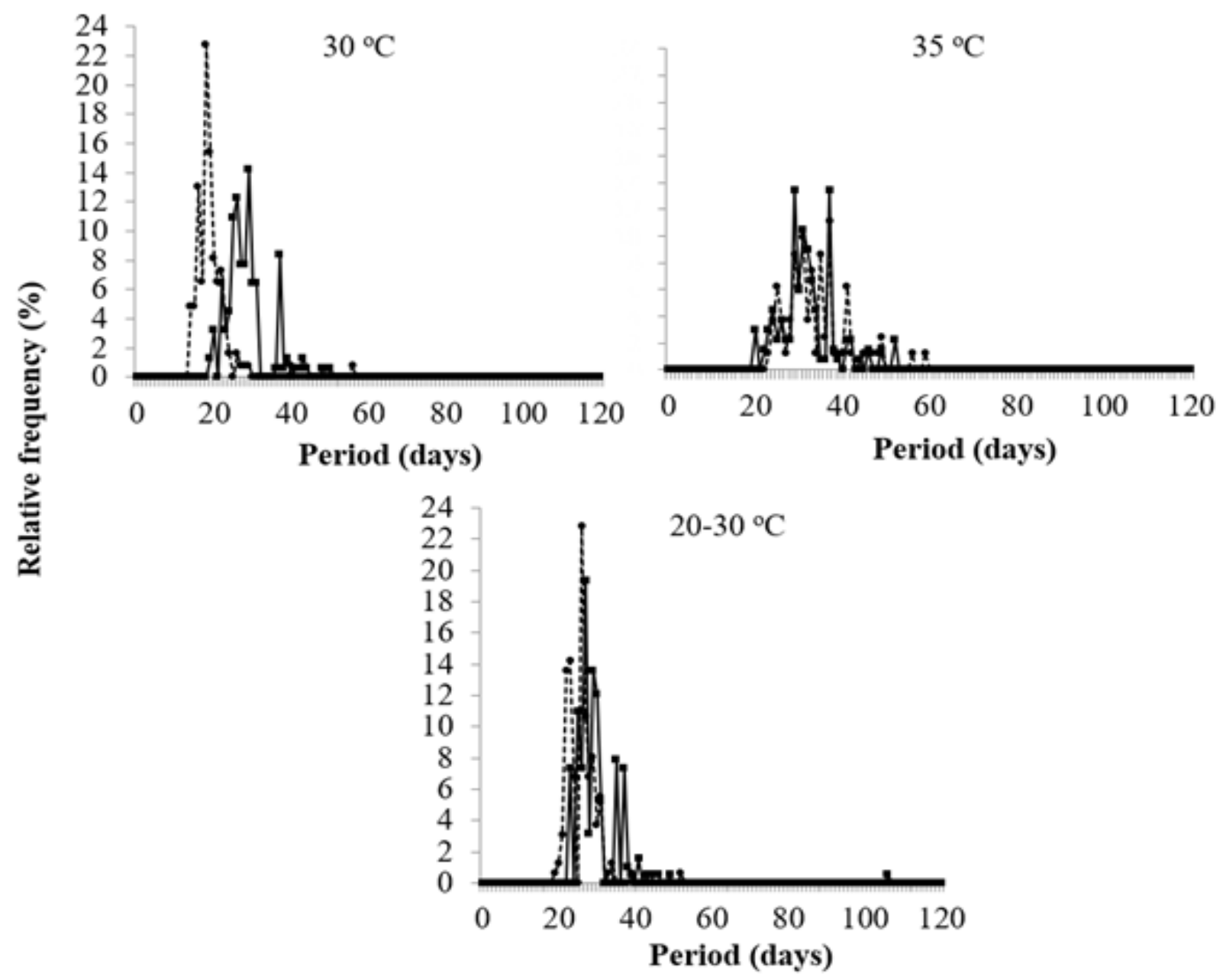

Figure 1. Relative frequency of germination of Ormosia arborea seeds at different temperatures and light conditions.

O. arborea seeds require a long period to germinate, as do many native species. Since there are no records in the literature regarding the tetrazolium test for this species, the improvement of tests that assess seed viability and characterize its physiological potential is greatly important.

Using the tetrazolium test, it was possible to separate $O$. arborea seeds into two categories concerning seed viability (Figure 2): Viable seeds, which presented reddish colored embryos, and unviable seeds, the ones that presented injuries in the embryonic axis. Most $(80 \%)$ of the seeds presented reddish colored embryos in the present work, classified as viable (Figure 2). However, further experiments with seed lots showing different physiological potential, salt concentrations, and exposure time are necessary to validate the tetrazolium methodology.

The viability results are following the mean germination percentage (Table 1) observed in this study. For Leucena seeds (Costa and Santos, 2010), Amburana cearensis (Guedes et al., 2010), Guibourtia hymenaefolia (Oliveira and Pereira, 2014), Tabebuia roseoalba (Abbade and Takaki, 2014), Enterolobium contortisiliquum (Nogueira et al., 2014) and Apuleia moralis (Reis et al., 2016), the tetrazolium test also was efficient to assess the viability of these seeds.

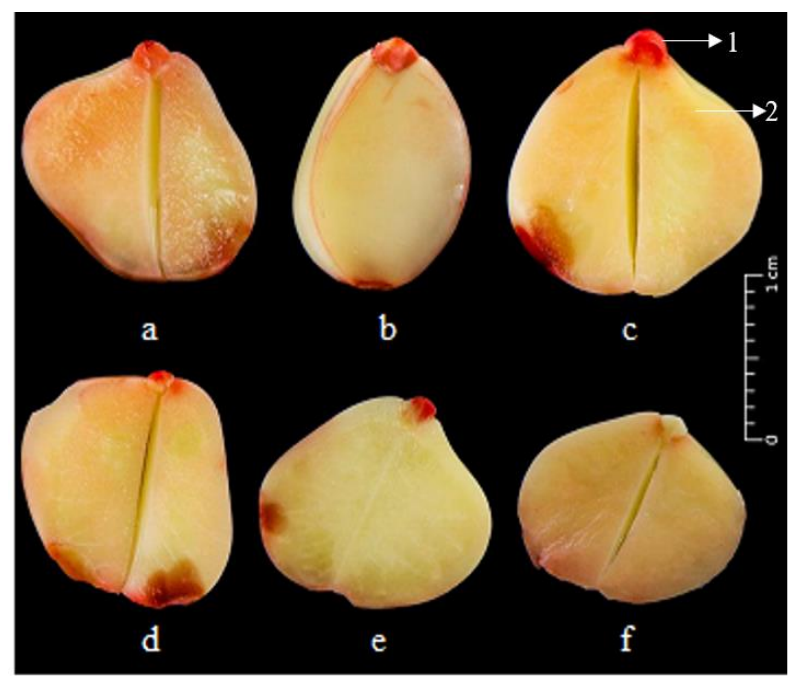

Figure 2. Classes of Ormosia arborea seeds in the tetrazolium test. A, B, and C: viable seeds presenting reddish color of the embryo; D, E, and F: unviable seeds presenting injuries in the embryonic axis. 1: embryonic axis; 2: cotyledon. 


\section{Conclusions}

The germination of Ormosia arborea seeds occurs in a wide range of temperatures, from 15 to $35{ }^{\circ} \mathrm{C}$ and regardless of the presence or absence of light. The temperatures of 25 and $30{ }^{\circ} \mathrm{C}$, and alternating temperatures of $20-30{ }^{\circ} \mathrm{C}$ are indicated to conduct germination tests. The tetrazolium test corroborates the obtained data in the germination test. It is efficient to analyze the viability of seeds with coat removed, longitudinally cut, immersed in a $0,075 \%$ tetrazolium solution at $35{ }^{\circ} \mathrm{C}$, for three hours. However, further experiments with seed lots of different qualities can establish a single temperature and light condition and establish a method of exposing seed tissue for staining. Also, different salt concentrations and exposure times are necessary to validate the tetrazolium test.

\section{Authors' Contribution}

Aparecida Leonir da Silva was responsible for the planning, material collection, development, and evaluation of the experiments. Halisson César Vinci Carlos and Rodrigo Cyrino Rivaben were responsible for the development and evaluation of the experiments. Prof. Laércio Junio Silva responsible for statistical analysis, Prof. Denise Cunha Fernandes dos Santos Dias responsible for correcting and interpreting the data, and Prof. Glaucia Almeida de Morais and Liana Baptista de Lima guided the planning, compiled the data, and coordinated the writing of the manuscript.

\section{Bibliographic References}

Abbade, L.C., Takaki, M. 2014. Teste de tetrazólio para avaliação da qualidade de sementes de Tabebuia roseoalba (Ridl.) Sandwith - Bignoniaceae, submetidas ao armazenamento. Revista Árvore, 38(2), 233-240. DOI: https://doi.org/10.1590/S0100-67622014000200003.

Araújo, J.O., Pinheiro, D.T., Dias, D.C.F.S., Hilst, P.C., Medeiros, A.D. 2019. Adequacy of the tetrazolium test to evaluate the viability of Jatropha curcas L. seeds. Journal of Seed Science, 41(4), 470-477. DOI: https://doi.org/10.1590/2317-1545v41n4223299.

Bewley, J.D., Black, M. 1982. Physiology and biochemistry of seeds in relation to germination: viability, dormancy, and environmental control, v. 2. New York, Springer.

Brancalion, P.H.S., Novembre, A.D.L.C., Rodrigues, R.R. 2010. Temperatura ótima de germinação de sementes de espécies arbóreas brasileiras. Revista Brasileira de Sementes, 32(4), 15-21. DOI: https://doi.org/10.1590/S010131222010000400002 .

Brasil. 2009. Ministério da Agricultura, Pecuária e Abastecimento. Regras para análise de sementes. Ministério da Agricultura, Pecuária e Abastecimento. Secretaria de Defesa Agropecuária. Brasília, MAPA.
Cardoso, V.J.M. 2004. Dormência: estabelecimento do processo. In: Ferreira, A.G., Borguetti, F. (Org.) Germinação: do básico ao aplicado. Porto Alegre, Artmed, p. 95-134.

Costa, C.J., Santos, C.P. 2010. Teste de tetrazólio em sementes de leucena. Revista Brasileira de Sementes, 32(2), 66-72. DOI: https://doi.org/10.1590/S0101-31222010000200008.

Daibes, L.F., Zupo, T., Silveira, F.A.O, Fidelis, A. 2017. A field perspective on effects of fire and temperature fluctuation on Cerrado legume seeds. Seed Science Research, 27(2), 74-83. DOI: http://dx.doi.org/10.1017/S096025851700006X.

Fenner, M. 2000. Seeds: the ecology and regeneration in plant communities, second ed. New York: CABI Publishing.

Ferreira, S.A.N., Gentil, D.F.O. 2017. Seed germination at different stratification temperatures and development of Phytelephas macrocarpa Ruiz \& Pavón seedlings. Journal of Seed Science, 39(1), 20-26. DOI: https://doi.org/10.1590/2317$1545 \mathrm{v} 39 \mathrm{n} 1166371$.

Footitt, S., Douterelo-Soler, I., Clay, H., Finch-Savage, W.E. 2011. Dormancy cycling in Arabidopsis seeds is controlled by seasonally distinct hormone-signaling pathways. Proceedings of the National Academy of Science of the United States of America, 108(50), 20236-20241. DOI: https://doi.org/10.1073/pnas.1116325108.

França-Neto, J.B., Krzyzanowski, F.C. 2019. Tetrazolium: an important test for physiological seed quality evaluation. Journal of Seed Science, 41(3), 359-366. DOI: http://dx.doi.org/10.1590/2317-1545v41n3223104.

Guedes, R.S., Alves, E.U., Gonçalves, E.P., Viana, J.S., Silva, K.B., Gomes, M.S.S. 2010. Metodologia para teste de tetrazólio em sementes de Amburana cearensis (Allemão) A.C. Smith. Revista Brasileira de Plantas Medicinais, 12(1), 120-126. DOI: https://doi.org/10.1590/S1516-05722010000100017.

Hössel, C., Oliveira, J.S.M.A., Fabiane, K.C., Wagner Júnior, A., Citadin, I. 2013. Conservação e teste de tetrazólio em sementes de jabuticabeira. Revista Brasileira de Fruticultura, $35(1)$, 255-261. DOI: https://doi.org/10.1590/S010029452013000100029 .

Huarte, H.R., Benech-Arnold, R.L. 2010. Hormonal nature of seed responses to fluctuating temperatures in Cynara cardunculus (L.). Seed Science Research, 20(1), 39-45. DOI: 10.1017/S0960258509990249.

Jaganathan, G.K., Han, Y., Song, D., Selvam, P., Liu, B. 2019. Maternal and burial environment determine the physical dormancy release in tropical Senna auriculata (Fabaceae) seeds. Journal of Forestry Research, 30(4), 1343-1351. DOI: http://dx.doi.org/10.1007/s11676-018-0699-1.

Kaiser, D.K., Freitas, L.C.N., Biron, R.P., Simonato, S.C., Bortolini, M.F. 2014. Adjustment of the methodology of the tetrazolium test for estimating viability of Eugenia uniflora L. seeds during storage. Journal of Seed Science, 36(3), 344-351. DOI: https://doi.org/10.1590/2317-1545v36n31022.

Labouriau, L.G., Pacheco, A. 1978. On the frequency of isothermal germination in seeds of Dolichos biflorus L. Plant and Cell Physiology, 19(3), 507-512. DOI: https://doi.org/10.1093/oxfordjournals.pcp.a075620. 
Labouriau, L.G., Valadares, M.E.B. 1976. On the germination of seeds of Calotropis procera (Ait.) Ait. F. Anais da Academia Brasileira de Ciências, 48(2), 263-284.

Lamarca, E.V., Barbedo, C.J. 2014. Methodology of the tetrazolium test for assessing the viability of seeds of Eugenia brasiliensis Lam., Eugenia uniflora L. and Eugenia pyriformis Cambess. Journal of Seed Science, 36(4), 427-434. DOI: http://dx.doi.org/10.1590/2317-1545v36n41029.

Larcher, W. 2006. Ecofisiologia vegetal. São Carlos, RIMA Artes e Textos.

Lopes, J.C., Capucho, M.T., Martins Filho, S., Repossi, P.A. 2005. Influência de temperatura, substrato e luz na germinação de sementes de bertalha. Revista brasileira de sementes, 27(2), 18-24. DOI: http://dx.doi.org/10.1590/S010131222005000200004 .

Lorenzi, H. 2000. Árvores Brasileiras: Manual de Identificação e Cultivo de Plantas Arbóreas Nativas do Brasil, terceira ed. Nova Odessa, Plantarum.

Marcos-Filho, J. 2015. Fisiologia de sementes de plantas cultivadas. Londrina, ABRATES.

Merai, Z., Graeber, K., Wilhelmsson, P., Ullrich, K.K., Arshad, W., Grosche, C., Tarkowská, D., Turečková, V., Strnad, M., Rensing, S.A., Leubner-Metzger, G., Scheid, O.M. 2019. Aethionema arabicum: a novel model plant to study the light control of seed germination. Journal of Experimental Botany, 70(12), 3313-3328. DOI: https://doi.org/10.1093/jxb/erz146.

Moore, R.P. 1972. Interpretation of color differences in tetrazolium testing. Seed Technologist News, 44(3), 22-24.

Naves, V.L., Rezende, R.M., Alcantra, E., Rezende, R.A.L.S. 2018. Superação de dormência de sementes de olho-de-cabra (Ormosia arborea) por diferentes métodos. Revista da Universidade do Vale do Rio Verde, 16(3), 1-8. DOI: http://dx.doi.org/10.5892/ruvrd.v16i3.5605.

Nogueira, N.W., Torres, S.B., Freitas, R.M.O. 2014. Teste de tetrazólio em sementes de timbaúba. Semina: Ciências Agrárias, 35(6), 2967-2976. DOI: 10.5433/16790359.2014v35n6p2967.

Oliveira, A.K.M., Pereira, K.C.L. 2014. Efeito de diferentes temperaturas na germinação e crescimento radicular de sementes de jatobá-mirim (Guibourtia hymenaefolia (Moric.) J. Léonard). Ciência Florestal, 24(1), 111-116. DOI: https://doi.org/10.5902/1980509813328.

Oliveira, A.K.M., Souza, J.S., Carvalho, J.M.B., Souza, S.A., Bocchese, R.A. 2016. Germinação de sementes e crescimento de Ormosia arborea em diferentes temperaturas e substratos. $\begin{array}{lll}\text { Gaia Scientia, 10(4), 262-271. DOI: } & \end{array}$ http://dx.doi.org/10.21707/gs.v10.n04a21.

Pimenta, S.M., Coelho, M.F.B., Sales, D.M., Azevedo, R.A.B., Albuquerque, M.C.F. 2011. Germinação de sementes de Kielmeyera coriacea em diferentes substratos e condições de luz. Revista de Biologia e Ciências da Terra, 11(2), 81-87.
Reis, A.R.S., Santos, J.X., Carvalho, J.C., Leão, N.V.M., Freitas, A.D.D., Shimizu, E.C. 2016. Germinação, teste de tetrazólio, condutividade elétrica e embebição de sementes de amarelão (Apuleia moralis Spruce ex. Benth. - Fabaceae). Informativo ABRATES, 26(1,2,3), 36-47.

Rosseto, J., Albuquerque, M.C.F., Rondon Neto, R.M., Silva, I.C.O. 2009. Germinação de sementes de Parkia pendula (Willd.) Benth. ex Walp. (Fabaceae) em diferentes temperaturas. Revista Árvore, 33(1), 47-55. DOI: https://doi.org/10.1590/S0100-67622009000100006.

Sarmento, M.B., Silva, A.C.S., Villela, F.A., Santos, K.L., 2018. Biometria de frutos e sementes e crescimento pósseminal de Acca sellowiana (O. Berg. Burret) Myrtaceae. Caderno de Pesquisa, 30 (1), 01-08. DOI: http://dx.doi.org/10.17058/cp.v30i1.8696.

Silva, A.L., Dias, D.C.F.S., Lima, L.B., Morais, G.A. 2014. Methods for overcoming seed dormancy in Ormosia arborea seeds, characterization and harvest time. Journal of Seed Science, 36(3), 318-325. DOI: https://doi.org/10.1590/2317$1545 v 36 n 31012$.

Silva, A.L., Morais, G.A. 2012. Biometry and dormancy breaking of Ormosia arborea seeds. Communications in Plant Sciences, 2(3-4), 105-107.

Silva, R.C., Grzybowski, C.R.S., França-Neto, J.B., Panobianco, M. 2013. Adaptação do teste de tetrazólio para avaliação da viabilidade e vigor em sementes de girassol. Pesquisa Agropecuária Brasileira, 48(1), 105-113. DOI: https://doi.org/10.1590/S0100-204X2013000100014.

Souza, T.V., Voltolini, C.H., Santos, M., Paulilo, M.T.S. 2012. Water absorption and dormancy-breaking requirements of physically dormant seeds of Schizolobium parahyba (FabaceaeCaesalpinioideae). Seed Science Research, 22(3), 169-176. DOI: https://doi.org/10.1017/S0960258512000013.

Souza Filho, J.C., Coelho, M.F.B., Azevedo, R.A.B., Albuquerque, M.C.F. 2012. Germinação de sementes de Magonia pubescens St. Hil. - Sapindaceae em diferentes condições de luz e fotoperíodo. Revista de Biologia e Ciências da Terra, 12(2), 14-19.

Teixeira, W.F., Fagan, E.B., Casaroli, D., Canedo, S.C., Barbosa, K.A. 2011. Avaliação de métodos para superação de dormência na germinação de Ormosia arborea (Vell.) Harms. Biotemas, 24(4), 25-29. DOI: https://doi.org/10.5007/21757925.2011v24n4p25.

Valadares, J., Paula, R.C. 2008. Temperaturas para germinação de sementes de Poecilanthe parviflora Bentham (FabaceaeFaboideae). Revista Brasileira de Sementes, 30(2), 164-170. DOI: https://doi.org/10.1590/S0101-31222008000200020. 